\title{
Rediscovery of the endemic Afrotropical genus Spathioplites (Hymenoptera, Braconidae, Doryctinae) with major range extension records for Spathioplites phreneticus
}

\author{
Simon van Noort ${ }^{1,2}$, Sergey A. Belokobylskij ${ }^{3,4}$, Agnièle Touret-Alby ${ }^{5}$ \\ I Research and Exhibitions Department, South African Museum, Iziko Museums of South Africa, P.O. Box 61, \\ Cape Town, 8000, South Africa 2 Department of Biological Sciences, University of Cape Town, Private Bag, \\ Rondebosch, 7701, South Africa 3 Zoological Institute Russian Academy of Sciences, St. Petersburg 199034, \\ Russia 4 Museum and Institute of Zoology Polish Academy of Sciences, Wilcza 64, Warszawa 00-679, Poland \\ 5 Muséum national d'Histoire naturelle, Entomologie - CP50 45 rue Buffon 75005 Paris, France \\ Corresponding author: Simon van Noort (svannoort@iziko.org.za) \\ Academic editor:Denis Brothers | Received 7 September 2021 | Accepted 30 October 2021 | Published 9 December 2021 \\ http://zoobank.org/6CDF8CC6-75B5-42C5-B423-E5E859A1D672 \\ Citation: van Noort S, Belokobylskij SA, Touret-Alby A (2021) Rediscovery of the endemic Afrotropical genus \\ Spathioplites (Hymenoptera, Braconidae, Doryctinae) with major range extension records for Spathioplites phreneticus. \\ African Invertebrates 62(2): 497-520. https://doi.org/10.3897/AfrInvertebr.62.74103
}

\begin{abstract}
The endemic, monotypic Afrotropical genus Spathioplites Fischer, 1962 is rediscovered based on new specimens collected in South Africa and Senegal. Spathioplites phreneticus Fischer, 1962 was previously known from the holotype (male) and 12 paratypes (11 males and a female) collected in Chad in 1959. As part of an ongoing long-term insect inventory survey program in Africa new specimens were recently collected in Tswalu Kalahari Game Reserve in South Africa, extending the distribution range southwards by $4900 \mathrm{~km}$. An additional historical specimen from Senegal was discovered in the collections of the Natural History Museum in Paris, extending the range westwards by $4000 \mathrm{~km}$. Possible reasons for the disjunct distribution exhibited by current locality records for this species are discussed. The holotype male and a paratype female, as well as one of the two newly collected South African females were imaged. These photographs, as well as genus and species re-descriptions, are provided. An identification key to the Old World genera in the doryctine tribe Spathiini s. str. is also presented. All images and interactive identification keys are available on www.waspweb.org.
\end{abstract}

Copyright Simon van Noort et al. This is an open access article distributed under the terms of the Creative Commons Attribution License (CC BY 4.0), which permits unrestricted use, distribution, and reproduction in any medium, provided the original author and source are credited. 


\section{Keywords}

Africa, distribution, identification key, inventory survey, Kalahari, parasitoid wasp, rare taxa, taxonomy, type photography

\section{Introduction}

The generic structure of the tribe Spathiini has undergone extensive changes in composition over the last 20 years. Previously, based only on assessment of morphological characters (defined mainly by the petiolate first metasomal tergite with a strongly elongated acrosternite) this tribe included 20 genera in seven subtribes (Belokobylskij 1992, 2002; Belokobylskij and Quicke 2000; Belokobylskij et al. 2004). However, more recent molecular phylogenetic studies of the doryctine genera changed the generic composition concept for this tribe (Zaldívar-Riverón et al. 2008; Jasso-Martínez et al. 2019). As a result, Platyspathius Viereck, 1911 and Antespathius Belokobylskij, 1995 (former subgenus of Spathius Nees, 1819) were transferred to the tribe Rhaconotini, Hemispathius Belokobylskij and Quicke, 2000 was included in the tribe Doryctini, and the group of the previously studied Neotropical Spathiini genera (including a number of genera from other tribes) were recovered in a well-supported South American clade, unrelated to the Old World spathiines. Currently, the Old World Spathiini includes the following eight genera: Afrospathius Belokobylskij and Quicke, 2000; Ceylonspathius Belokobylskij, 2002; Parana Nixon, 1943; Paraspathius Nixon, 1943; Spathioplites Fischer, 1962; Spathius Nees, 1819; Termitospathius Belokobylskij, 2002 and Toka Nixon, 1943 (Yu et al. 2016). Unfortunately, molecular sequence data have not yet been extracted for most of the Old World spathiines, namely Afrospathius, Ceylonspathius, Parana, Paraspathius, Spathioplites, Termitospathius and Toka, and as a result new molecular data may correct their supergeneric placement.

We provide an illustrated re-description of the Afrotropical genus and species Spathioplites phreneticus Fischer, 1962 and novel information about the species distribution, which exhibits a disruptive distributional pattern across the arid areas of the African continent. An illustrated identification key to the Old World genera in the doryctine tribe Spathiini s. str. is presented. All images and interactive identification keys are available on WaspWeb (van Noort 2021).

\section{Methods and materials}

\section{Field work}

Long-term, continuously run, inventory survey sites were deployed by Simon van Noort at eight localities across the representative vegetation types present in Tswalu 
Kalahari Game Reserve and run from October 2015 until May 2017. These surveys comprised deployment of Malaise traps, yellow pan traps, pitfall traps and yellow funnel traps, which operated continuously using propylene glycol as the preservative, and were serviced on a 6-8 weekly basis. The insect traps generated 186 bulk samples of insects, comprising thousands of specimens. The Malaise traps were frequently damaged or destroyed by game animals during this inventory survey, even though white barrier ropes were erected around the traps to make them more visible to animals. The solution would have been to completely surround the Malaise trap with a 2 meter high wire mesh fence, but logistics did not allow for this. Five different vegetation types were sampled: Gordonia Plains Shrubland, Gordonia Duneveld, Kathu Bushveld, Koranna-Langeberg Mountain Bushveld, and Olifantshoek Plains Thornveld in the Kalahari ecosystem, vegetation classification after Mucina and Rutherford (2006).

\section{Terminology}

Terminology employed for morphological features and measurements follows Belokobylskij and Maetô (2009). The wing venation nomenclature follows Belokobylskij and Maetô (2009), with van Achterberg's (1993) terminology shown in parentheses.

\section{Photography}

Images were acquired at SAMC with a Leica LAS 4.9 imaging system, comprising a Leica Z16 microscope with a Leica DFC450 Camera and $0.63 \times$ video objective attached. The imaging process, using an automated Z-stepper, was managed using the Leica Application Suite V 4.9 software installed on a desktop computer. Diffused lighting was achieved using a Leica LED 5000 Dome. Multilayer images were acquired at MNHN using a Canon EOS 6D camera (Tokyo, Japan) with MP-E 65mm Macro f/2.8 lens, associated with a Cognisys Rail macro Stack Shot (Traverse City, MI, USA) driven by the software Helicon Remote (Kharkiv, Ukraine; http://www.heliconsoft. com /). Resulting photographs were combined with Helicon Focus 6. All images included in this paper, as well as additional images are available on WaspWeb: www. waspweb.org (van Noort 2021) and images of the types are available on the MNHN's science collections' website: https://science.mnhn.fr.

\section{Depositories}

MNHN Muséum national d'Histoire naturelle, Paris, France (Curator: Bernardo Santos);

SAMC Iziko South African Museum, Cape Town, South Africa (Curator: Simon van Noort);

NHMW Natural History Museum, Vienna, Austria (Curator: Dominique Zimmerman). 


\section{Results}

Identification key to the Old World Spathiini genera

$1 \quad$ All femora (especially fore femora) with a distinct ventral tooth present subapically (A). Metapleural lower lobe indistinct (B). Palpal segment formula $5+3$. Body surface almost entirely polished (B)

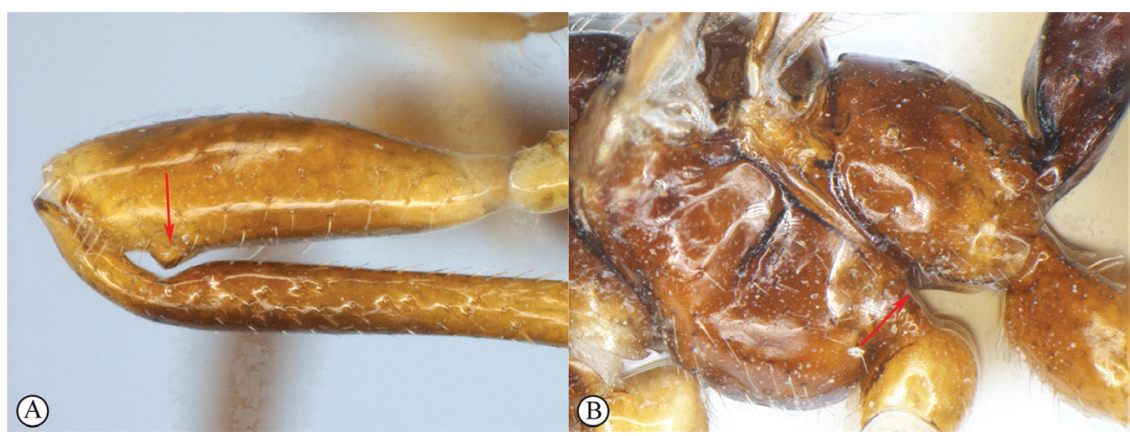

- $\quad$ All femora without a ventral tooth subapically (a). Metapleural lower lobe distinctly projected (b). Palpal segment formula $6+4$. Body surface at least partly sculptured (b) 3
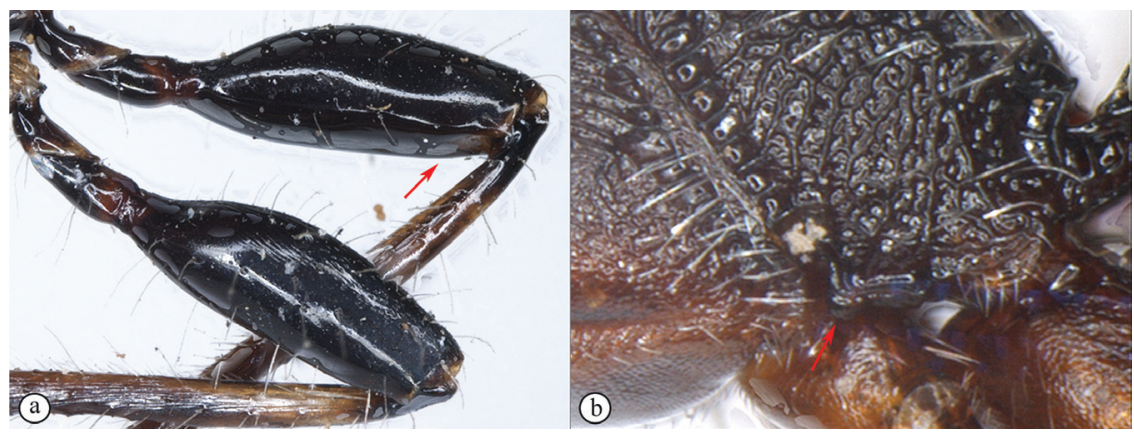

2 Prepectal (epicnemial) carina present (A). Propodeum without depressions (B). Third to sixth metasomal tergites covered with short setae (C)

Termitospathius Belokobylskij

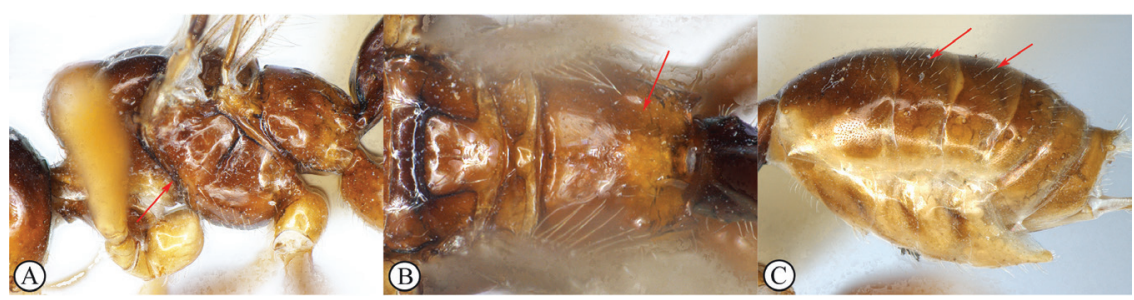


- $\quad$ Prepectal (epicnemial) carina absent (a). Propodeum with several depressions (b). Third to sixth metasomal tergites completely bare (c) ....

Ceylonspathius Belokobylskij

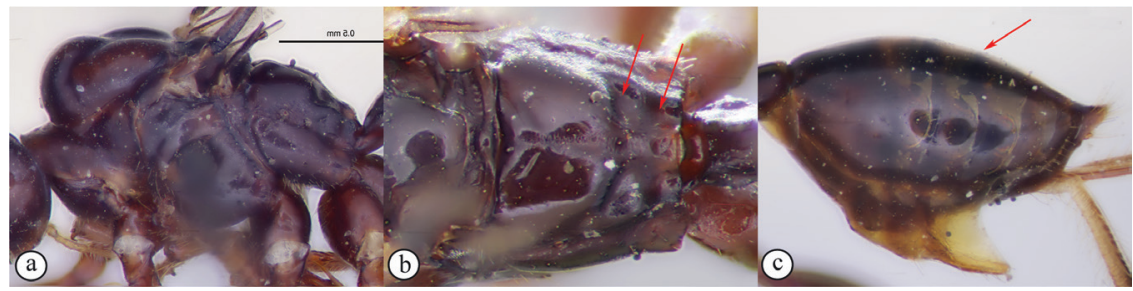

Brachial (subdiscal) cell of fore wing widely open postero-distally (A). Second metasomal tergite with distinct, complete and posteriorly convergent longitudinal furrows (B). In male, second radiomedial vein $(\mathrm{r}-\mathrm{m})$ of fore wing absent. Radial (basal) cell of fore wing distinctly shortened

Afrospathius Belokobylskij and Quicke

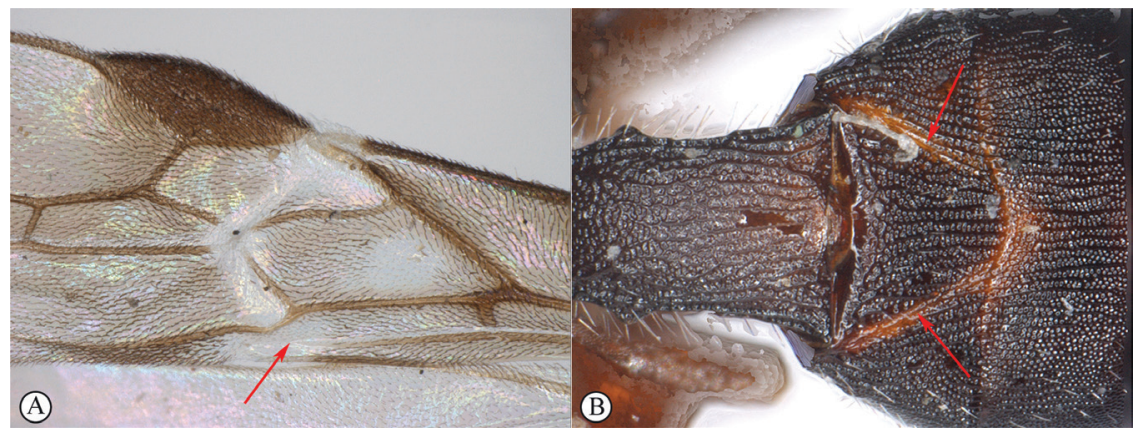

- $\quad$ Brachial (subdiscal) cell of fore wing closed postero-distally (a). Second metasomal tergite without longitudinal furrows (b). In male, second radiomedial vein $(r-m)$ of fore wing present. Radial (basal) cell of fore wing not shortened.

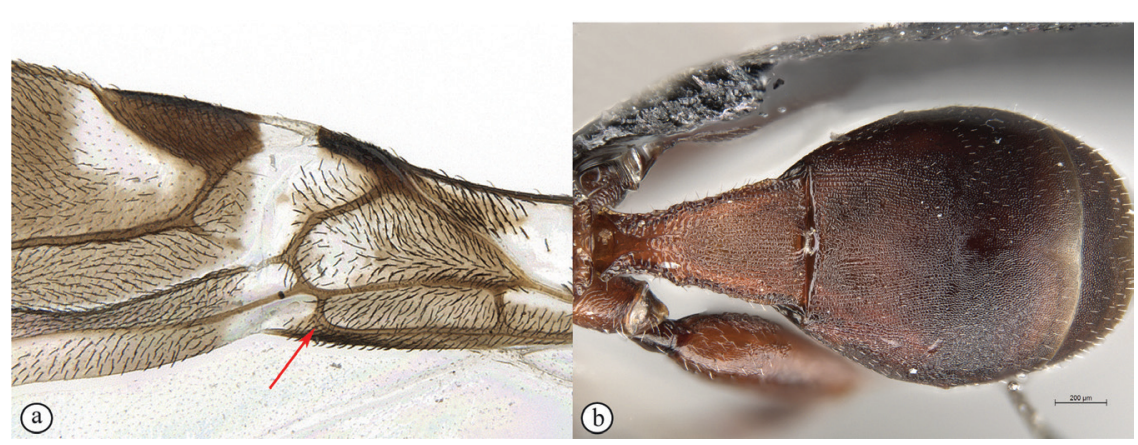


$4 \quad$ Frons and vertex laterally with distinctly raised protuberances (A). Antenna subclavate, widened and dorso-ventrally flattened apically (A). Metanotum with a long dorsal, laterally compressed lamella in form of inverted triangle (A, B). Metacarp (1-R1) of fore wing ephemeral in distal half (C). Recurrent vein $(\mathrm{m}-\mathrm{cu})$ of fore wing antefurcal, arising basad of first radiomedial vein (2RS) (C). Hind tibia with several short and thick spines along its dorsal margin

Spathioplites Fischer
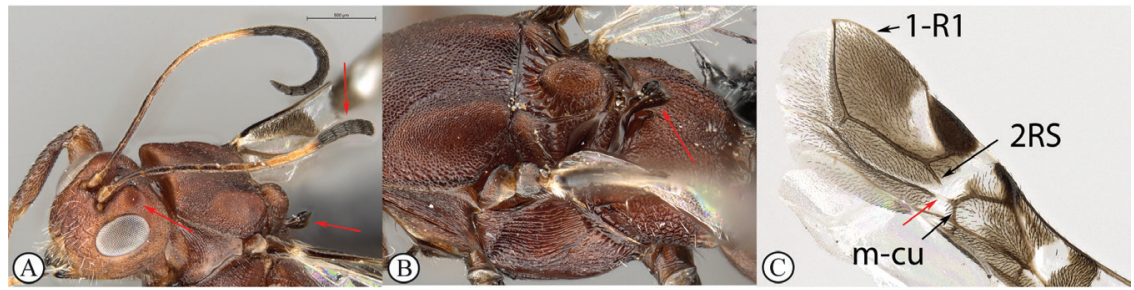

- $\quad$ Frons and vertex without raised protuberances (a). Antenna not widened apically. Metanotum without such dorsal lamella (b). Metacarp (1-R1) of fore wing complete (c). Recurrent vein (m-cu) of fore wing postfurcal, arising apicad of first radiomedial vein (2RS) (c). Hind tibia without any spines along its dorsal margin. .5
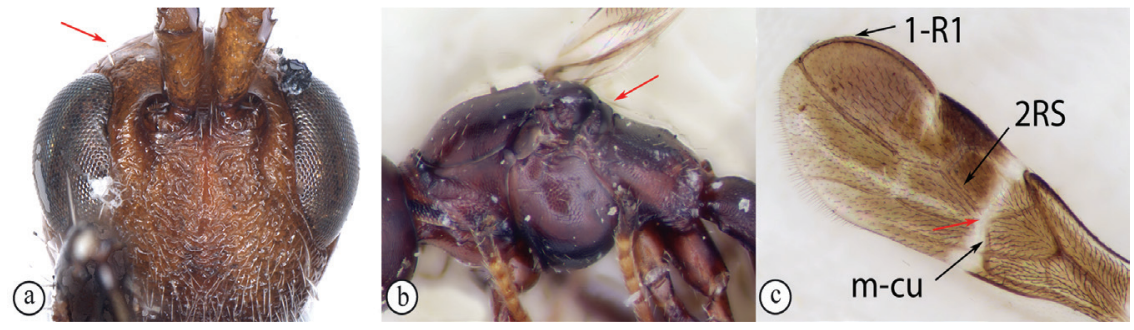

Nervulus (cu-a) of fore wing distinctly antefurcal to $\mathrm{M}+\mathrm{CU} / 1 \mathrm{M}$ junction (A). Basal vein (1r-m) of hind wing absent, costal vein $(1-S C+R)$ fused with mediocubital vein (1-M) (A)

Parana Nixon

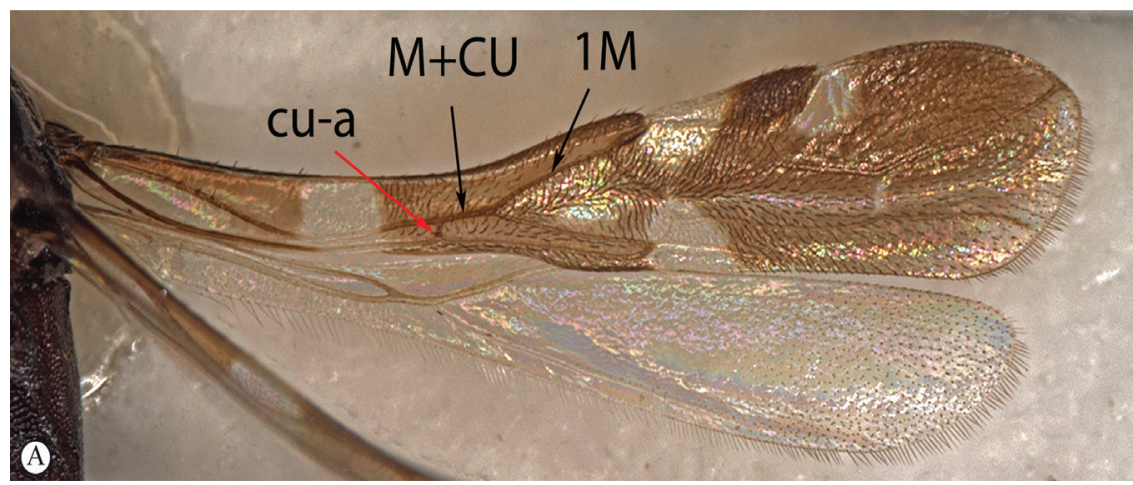


- $\quad$ Nervulus (cu-a) of fore wing postfurcal or interstitial to M+CU / $1 \mathrm{M}$ junction (a). Basal vein $(1 \mathrm{r}-\mathrm{m})$ of hind wing present, costal vein $(1-\mathrm{SC}+\mathrm{R})$ not fused with mediocubital vein (1-M) (a)

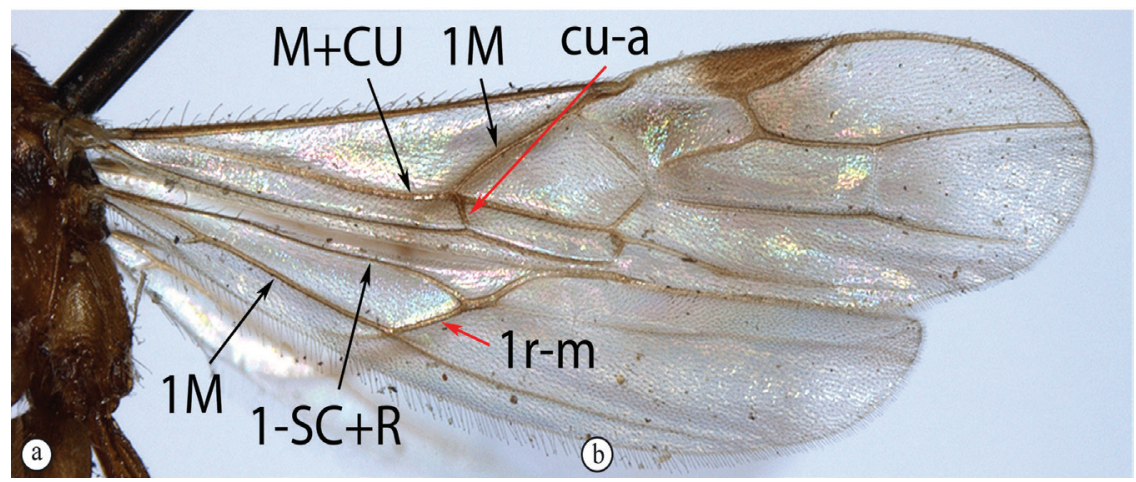

Precoxal sulcus absent (A). Metacarp (1-R1) of fore wing on outside margin almost without setae (B). Nervulus (cu-a) of fore wing strongly postfurcal to $\mathrm{M}+\mathrm{CU} / 1 \mathrm{M}$ junction (B).

Toka Nixon

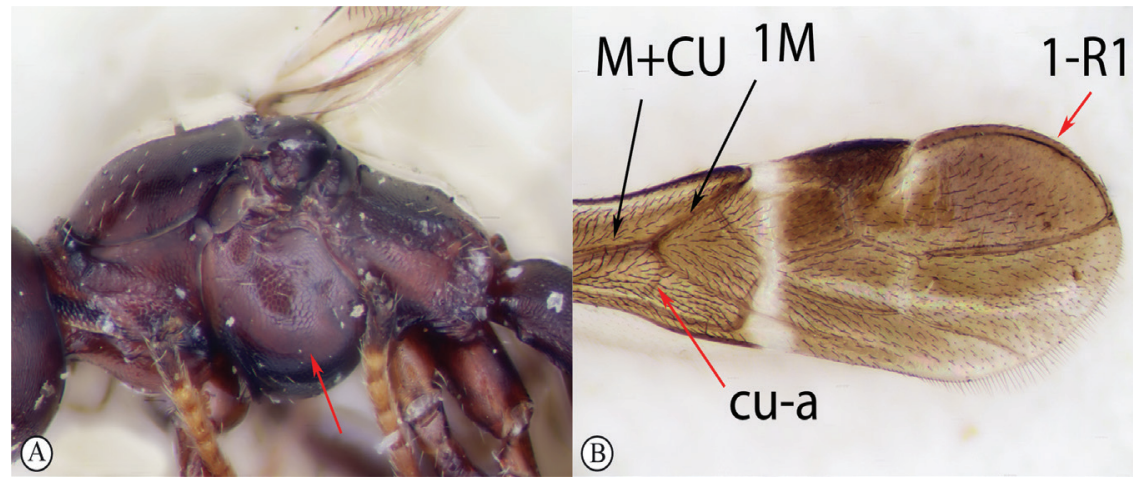

- $\quad$ Precoxal sulcus present (a). Metacarp (1-R1) of fore wing on outside margin densely setose (b). Nervulus (cu-a) of fore wing interstitial, or weakly postfurcal to $\mathrm{M}+\mathrm{CU} / 1 \mathrm{M}$ junction (b).

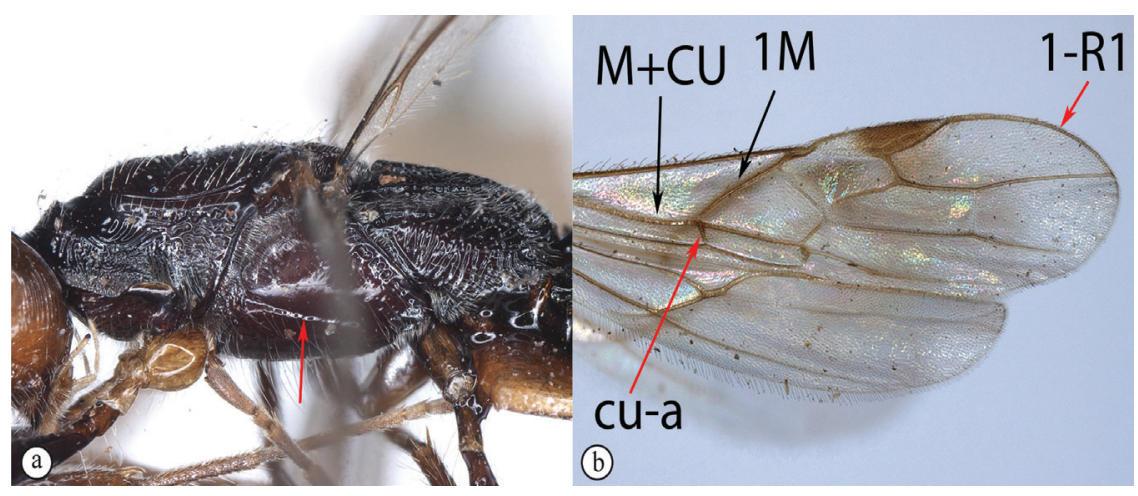


$7 \quad$ Scape of antenna long, about $2.0 \times$ as long as wide with distinct projection on the ventral apical margin in lateral view (A). Notauli absent (B).

Paraspathius Nixon

(A)

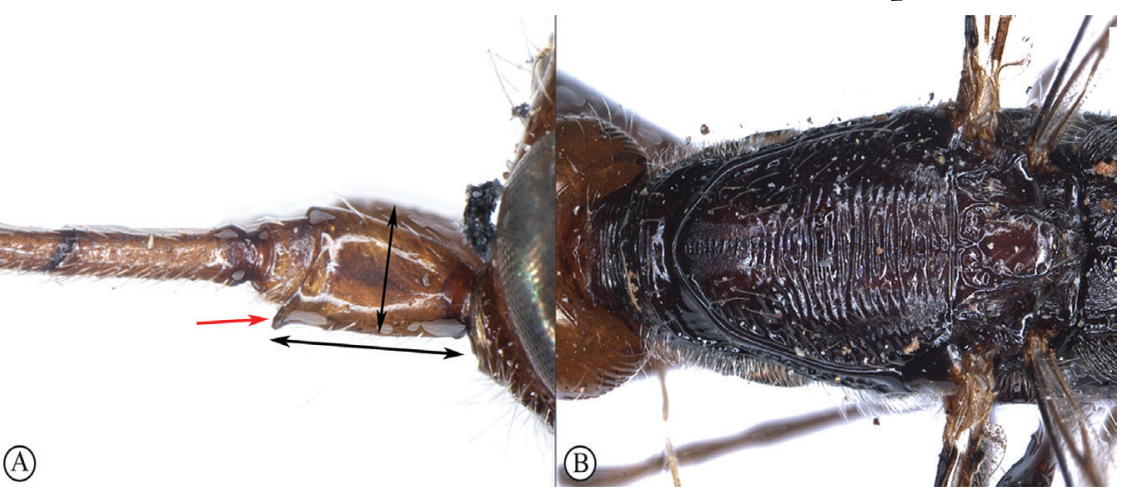

- $\quad$ Scape of antenna short, about $1.5 \times$ as long as wide, without projection on the lower apical margin in lateral view (a). Notauli present (b) .... Spathius Nees

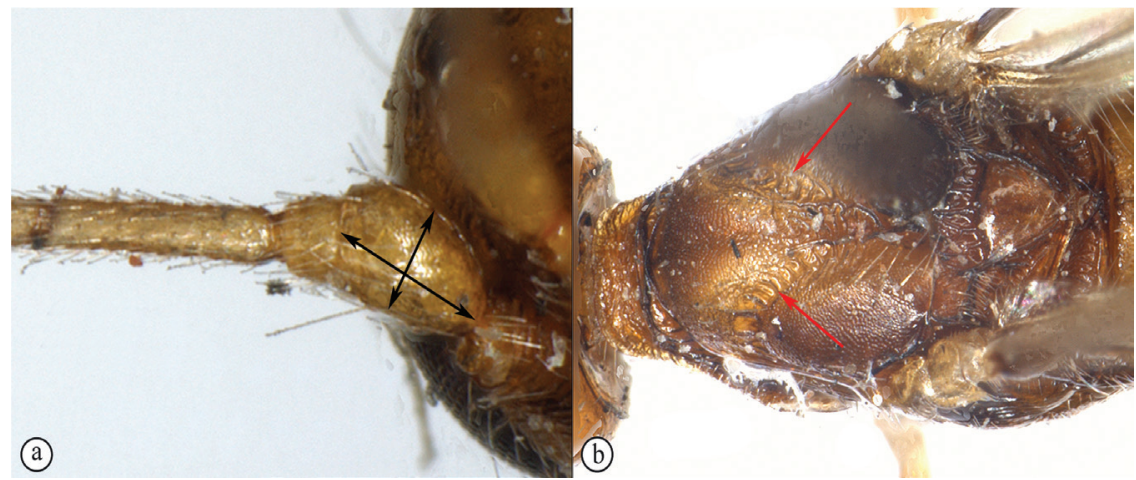

\section{Spathioplites Fischer, 1962}

Type species. Spathioplites phreneticus Fischer, 1962. Holotype in Paris (MNHN).

Type locality. Ennedi, Ouedi, Harisohi, Chad.

Re-description of the genus. Head not depressed, high, transverse. Ocelli arranged in triangle with base slightly larger than its sides. Vertex laterally of ocelli and frons laterally with distinct but not high longitudinal protuberances. Frons distinctly concave, with fine median longitudinal carina. Eyes glabrous. Occipital carina dorsally complete, fused ventrally with hypostomal carina. Malar suture rather distinct and complete. Clypeus without lower flange. Hypoclypeal depression small and round. Postgenal bridge wide. Maxillary palp short, 6-segmented, sixth segment about as long as fifth segment; labial palpi 4-segmented, third segment long. Antenna weakly claviform, all flagellar segments (especially apical ones) distinctly compressed. Scape of antenna wide and short, without apical lobe or basal constriction, its ventral margin 
(in lateral view) shorter than dorsal margin. First flagellar segment weakly compressed, weakly curved outer, as long as second segment. Apical segment obtuse or very weakly acuminated, without spine on tip.

Mesosoma not depressed, medium length. Neck of prothorax short, without pronope. Pronotum dorsally (lateral view) weakly convex, anterior part vertical; pronotal carina absent; anterior flange indistinct. Propleural dorsoposterior flange short and rather wide. Mesonotum highly and strongly oblique forward (visorshaped) elevated above pronotum. Median lobe of mesonotum distinctly separated, strongly protruding forwards, anteriorly with sharp transverse ridge, without median longitudinal furrow, without distinct anterolateral corners. Notauli complete, narrow, rather deep, but shallow posteriorly. Prescutellar depression (scutal sulcus) large, almost completely surrounding raised scutellum (except for short posterior margin of scutellum), coarsely crenulate. Scuto-scutellar suture distinct and complete. Scutellum narrow, oval, highly convex, without lateral carinae. Mesopleural pit distinct, subcircular, connected with mesopleural suture by shallow and slender furrow. Metanotum (lateral view) with very long, flat, and subtriangular median lobe, in dorsal view with slender lateral subparallel carina. Precoxal sulcus rather deep, relatively long, sinuate or straight. Prepectal carina distinct, weakly widened below, laterally extending to meet subalar depression. Postpectal carina absent. Metapleural flange short, rather wide, rounded apically. Propodeum distinctly slanted from almost middle to posterior margin, without areas delineated by carinae; lateral propodeal tubercles short and wide or indistinct; propodeal bridge absent. Propodeal spiracles small and round. Metapleural suture distinct.

Wings. Fore wing margins mainly glabrous, only with very short setae on its apico-posterior margin. Pterostigma wide. Radial vein ( $\mathrm{r}$ ) arising before middle of pterostigma. Radial (marginal) cell large, wide, weakly shortened. Metacarp (1-R1) fine and usually unpigmented in basal $0.5-0.6$, absent or almost absent in apical $0.4-$ 0.5 . Both radiomedial veins (2-SR and $\mathrm{r}-\mathrm{m})$ present. Recurrent vein ( $\mathrm{m}-\mathrm{cu})$ distinctly antefurcal. Discoidal (discal) cell of female petiolate anteriorly, petiole (1-SR) short and thick; but in male (holotype) discoidal cell sessile after fused with wide and thickened part of veins and parastigma. Mediocubital vein $(\mathrm{M}+\mathrm{CU} 1)$ strongly sinuate, strongly curved toward anal vein (1-1A) in its apical half. Nervulus (cu-a) postfurcal. Parallel vein (CU1a) interstitial. Brachial (subdiscal) cell wide, sharply roundly closed postero-apically. Transverse anal veins $(2 \mathrm{~A}$ and a) absent. Hind wing with three hamuli. Radial vein (SR) arising from costal vein (2-SC+R) far from basal vein (1r-m). Radial (marginal) cell very wide, distinctly widened towards apex. Medial (basal) cell rather wide, weakly widened towards apex, $0.4 \times$ as long as hind wing. Last abscissa of medial vein (2-M) practically absent or indistinct. Nervellus (cu-a) present. Submedial (subbasal) cell long. First abscissa of mediocubital vein $(\mathrm{M}+\mathrm{CU}) 1.1-1.2 \times$ as long as second abscissa (1-M). Recurrent vein (m-cu) long, strongly desclerotized, weakly curved or almost straight, distinctly oblique toward base of wing.

Legs. Fore tibia with several short and slender spines arranged in rather wide stripe. Middle tibia with distinct, short and thick spines arranged in narrow stripe along its 
dorsal margin. All tibiae distinctly thickened. Middle tarsal segments rather short. Hind coxa short, wide, subround, without basoventral corner and tooth. All femora wide, without dorsal protuberance. Hind femur elongate-oval, wide. Hind tibia with several short and thick spines along its dorsal margin. Basitarsus of hind tarsus short, about $0.5 \times$ as long as second to fifth segments combined.

Metasoma. First tergite semi-petiolate, rather long and wide. Acrosternite of first segment distinctly elongate, $0.45-0.50 \times$ as long as first tergite, its anterior margin placed at level of spiracles or behind it. Dorsope and basolateral lobes of first tergite absent or small. Distinct spiracular tubercles situated in basal $0.35-0.40$ of first tergite; dorsal carinae absent, but rather distinct in basal half in male. Second and third tergites without any furrows and areas, but in male with rather distinct and almost complete, weakly divergent posteriorly sublateral (started from anterolateral corner) and not high longitudinal carinae. Suture between second and third tergites indistinct or very fine (in male). Laterotergites of second and third tergites not fused laterally with each other. Second to fifth (in female) or second to fourth (in male) tergites with separate laterotergites. Fourth to sixth tergites with relatively wide stripe of short, sparse, semierect pale setae in their posterior halves. Fourth tergite of female weakly enlarged, almost entirely covering following segments; apical segments only weakly protruding behind fourth tergite; but in male, tergites behind third tergite the same length and all protruding. Hypopygium in posterior margin with distinct pointed median process. Ovipositor apically without dorsal nodes. Ovipositor sheath distinctly not widened towards apex, shorter than metasoma.

Diagnosis. The genus Spathioplites is characterized by the combination of the following diagnostic apomorphic characters: antenna apically widened and flattened; frons and vertex anteriorly with lateral protuberances; metanotum with long, flat and distally strongly widened median process; hind tibia with distinct strong spines along the dorsal margin; petiole (1-SR) of discoidal (discal) cell of fore wing in female large and thick; metacarp (1-R1) absent in distal half; submedial cell of hind wing long; acrosternite of first metasomal segment elongate, about as long as half of tergite; prescutellar depression situated around the most part of scutellum. On the basis of these listed diagnostic characters, Spathioplites was placed in the monotypic subtribe Spathioplitina of the tribe Spathiini (Belokobylskij 1992).

Comments. Position of this genus in Spathiini is still questionable, because the acrosternite of the first metasomal segment is not strongly elongated and is only about half as long as the first tergite. This genus is additionally characterized by the presence of distinct spines on the dorsal side of the hind tibia, a character which is also known in the Doryctini group of Doryctophasmus genera (including Doryctophasmus Enderlein, 1912, Esterella Pagliano and Scaramozzino, 1990, Euscelinus Westwood, 1882, and Sonanus Belokobylskij and Konishi, 2001) (Belokobylskij 2015), but Spathioplites is taxonomically not related to the members of this group. Perhaps only molecular data will help to resolve the tribal position of this very peculiar genus, and reveal whether it actually belongs to the tribe Doryctini, Rhaconotini or Spathiini.

Distribution. Afrotropical Region: Chad, Senegal, South Africa. 


\section{Spathioplites phreneticus Fischer, 1962}

Figures 1-5

Spathioplites phreneticus Fischer, 1962: 303; Yu et al. 2016. Holotype in Paris (MNHN).

Type locality: Ennedi, Ouedi, Harisohi, Chad.

Spathioplites phreneticus van Achterberg, 1993: 94, plate 8 (paratype female illustrated).

Material examined. Holotype. CHAD • ${ }^{\top}$; Afr. equat. fr., Ennedi, Ouedi [17.73230, 21.88331], Harischi; 1959; J. Mateu; ex Lyctus hipposideros Lesne vel Enneadesmus forficula Fairm [handwritten label]; Spathioplites phreneticus sp. nov., det. Fischer; Holotypus (pink label); EY3209 (MNHN). http://coldb.mnhn.fr/catalognumber/mnhn/ey/ey3209

Paratypes. CHAD $~ 1 \%$; Afr. equat. fr., Ennedi, Ouedi, Harischi; 17 th August [handwritten on the back of the locality label] 1959; J. Mateu; ex A. raddiana [handwritten label]; Spathioplites phreneticus sp. nov., det. Fischer; Allotype (pink label); † Spathioplites phreneticus Fischer, C. van Achterberg, 1980, Paratype (blue label); EY3258 (MNHN) http://coldb.mnhn.fr/catalognumber/mnhn/ey/ey3258 • 1 ô; Afr. equat. fr., Ennedi, Ouedi, Harischi; $17^{\text {th }}$ August [handwritten on the back of the locality label] 1959, J. Mateu; ex A. raddiana [handwritten label]; Spathioplites phreneticus sp. nov., det. Fischer; paratype (pink label); EY32026 (MNHN) http://coldb.mnhn. $\mathrm{fr} /$ catalognumber/mnhn/ey/ey32026 • $4 \widehat{\jmath} \widehat{\jmath}$ Afr. equat. fr., Ennedi, Ouedi, Harischi; 1959, J. Mateu; ex A. raddiana [handwritten label]; Spathioplites phreneticus sp. nov., det. Fischer; paratype (pink label) (NHMW) $-2 \hat{\jmath}$ Afr. equat. fr., Ennedi, Ouedi, Harischi; 1959; J. Mateu; ex Lyctus hipposideros Lesne vel Enneadesmus forficula Fairm [handwritten label]; Spathioplites phreneticus sp. nov., det. Fischer; paratype (pink label) (NHMW) • $1 \delta^{\Uparrow}$ Afr. equat. fr., Ennedi, Ouedi, Harischi; 1959; J. Mateu; ex Coleoptera (Holzbohrer) an Acacia; Spathioplites phreneticus sp. nov., det. Fischer; paratype (pink label) (NHMW).

Comments. According to the material cited in Fischer's original description there should be 13 type specimens with dates of collection as follows: 13.VIII.1959: 60;; 17. VIII.1959: 50 and 19; 6. V.1959: 10 . Only 10 of these types have been located: the holotype male and two paratypes (male and female) in MNHN, and 7 paratype males in NHMW.

Additional material. SENEGAL •19; Bambey; [14.719248, - 16.460502]; J. Risbec; R. $84(\mathrm{MNHN})$; South Africa 1 1 9 ; Northern Cape, Tswalu Kalahari Reserve,

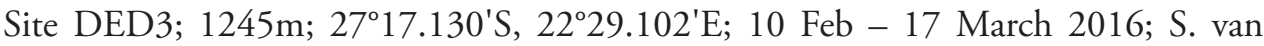
Noort; Malaise trap; Olifantshoek Plains Thornveld, Savanna Biome; TSW15-DED3M14; SAM-HYM-P086343 (SAMC) •19; Northern Cape, Tswalu Kalahari Reserve, Site DED3; $1245 \mathrm{~m} ; 27^{\circ} 17.130^{\prime} \mathrm{S}, 2^{\circ} 29.102^{\prime} \mathrm{E} ; 17$ March - 9 May 2016; S. van Noort; Malaise trap; Olifantshoek Plains Thornveld, Savanna Biome; TSW15-DED3M19; SAM-HYM-P095175 (SAMC).

Redescription. Female. Body length 3.5-3.8 mm; fore wing length $2.0-2.3 \mathrm{~mm}$.

Head width $1.3 \times$ median length, 1.0-1.1× width of mesoscutum. Head behind eyes (dorsal view) convex in anteriorly half and roundly narrowed in posterior half. 


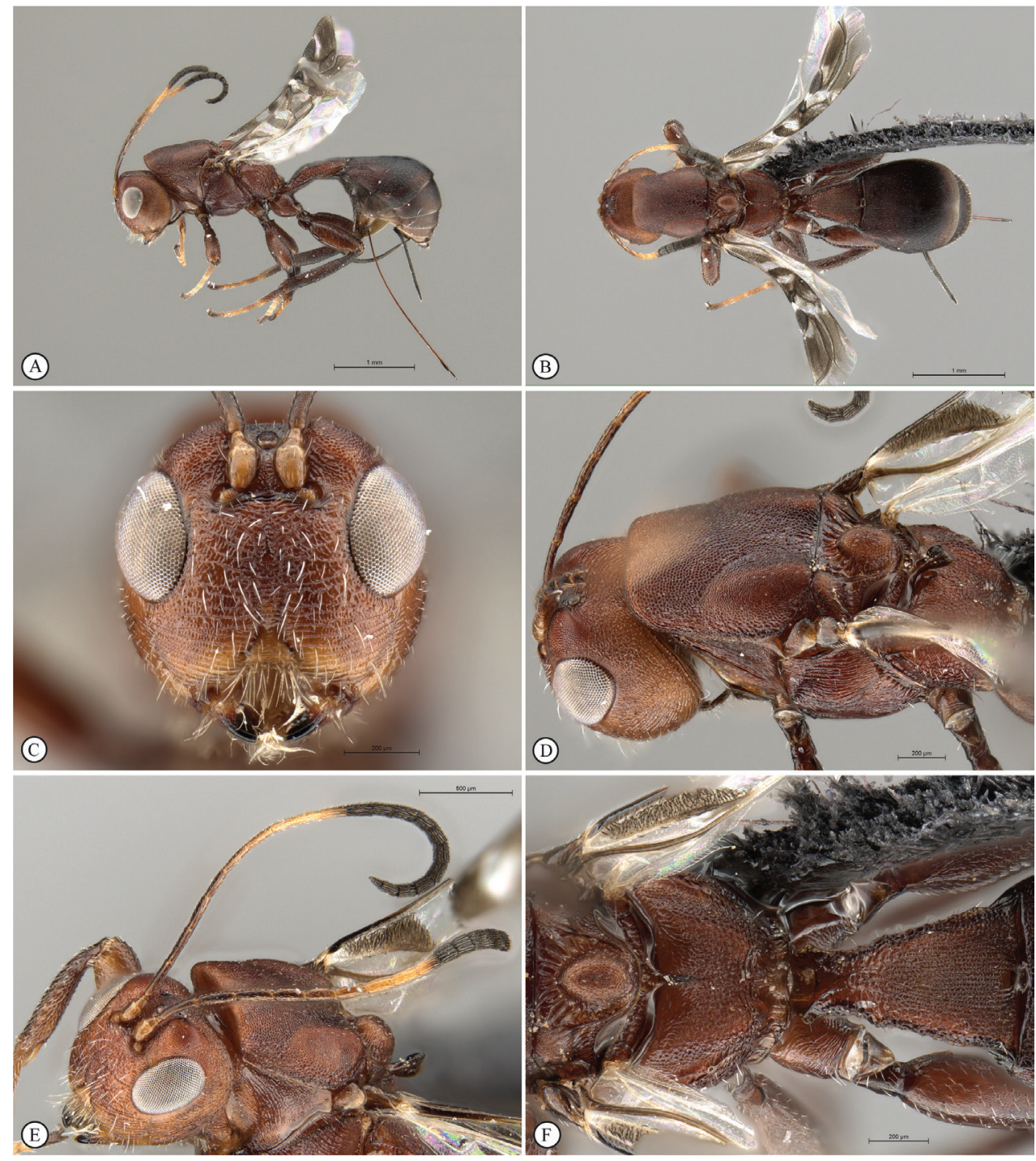

Figure I. Spathioplites phreneticus, female South Africa SAM-HYM-P086343 (SAMC) A habitus, lateral view B habitus, dorsal view $\mathbf{C}$ head, anterior view $\mathbf{D}$ head, mesosoma, dorso-lateral view $\mathbf{E}$ antennae, head, mesosoma, antero-dorsal view $\mathbf{F}$ scutellum, propodeum, first tergite, dorsal view.

Transverse diameter of eye about as long as temple (dorsal view). Ocelli small, in triangle with base $1.1 \times$ its sides. POL $1.5-1.8 \times$ Od, about $0.4 \times$ OOL. Eyes with very fine emargination opposite antennal sockets, distinctly directed forwards (lateral view), $1.4 \times$ as high as broad. Malar space $0.8 \times$ maximum diameter of eye, $1.2 \times$ basal width of mandible. Face convex, its minimum width $1.2 \times$ height of eye and $0.9 \times$ height of face and clypeus combined. Hypoclypeal depression width $0.4 \times$ distance from edge of depression to eye, $0.3 \times$ width of face. Head below eyes (front view) strongly and roundly narrowed. Hypostomal flange narrow. 


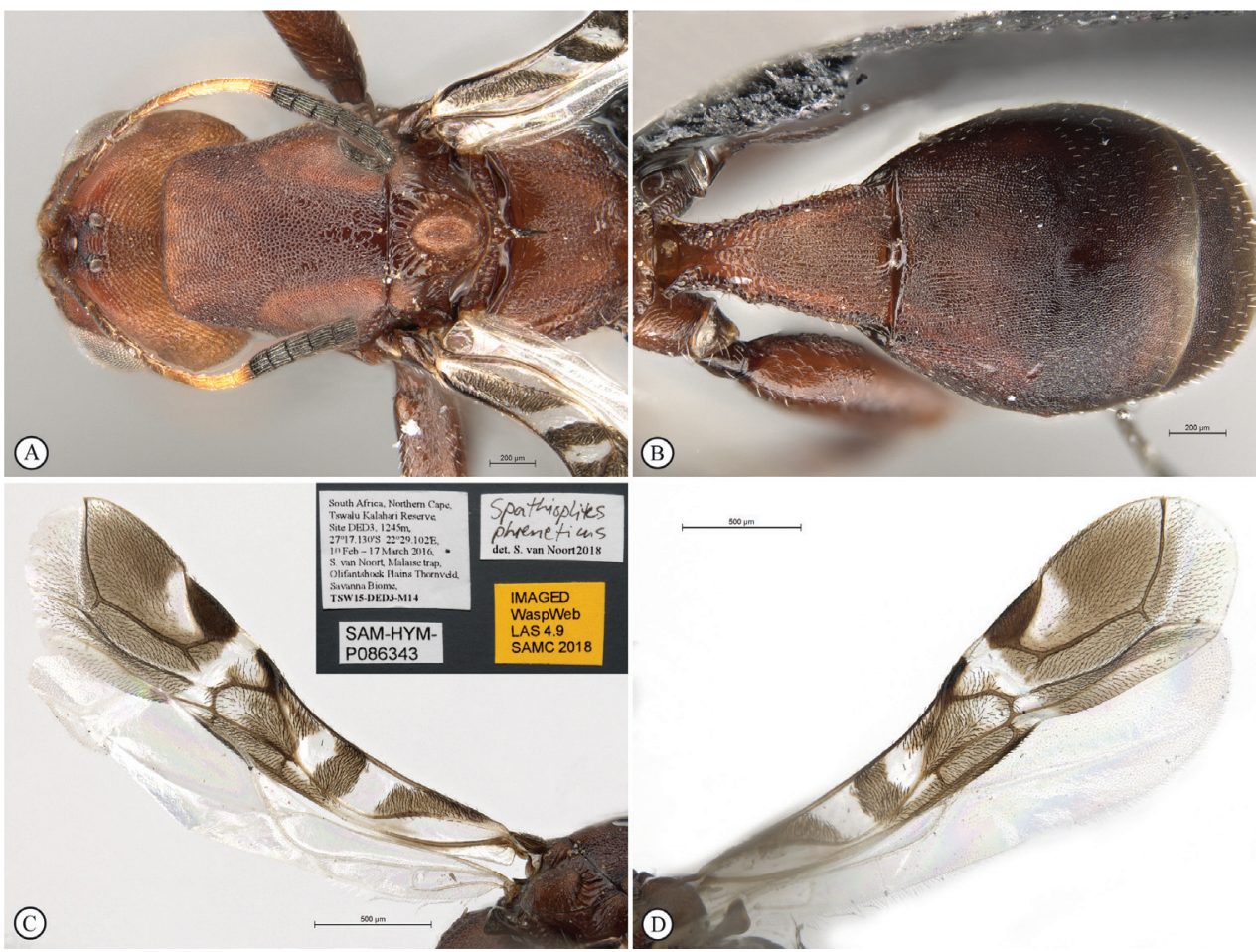

Figure 2. Spathioplites phreneticus, female South Africa SAM-HYM-P086343 (SAMC) A head, mesosoma, dorsal view B metasoma, dorsal view $\mathbf{C}$ left wings, dorsal view (inset: data labels) D right wings, dorsal view (note that both sets of depicted wings (C, D) have dried in a contorted manner and are curved and folded, distorting dimensions of the constituent cells, which is evident when comparing the two images).

Antenna narrow basally and widened apically, 19 to 20 segmented, about $0.6 \times$ as long as body. Scape 1.4-1.6x longer than its maximum width. First flagellar segment (lateral view) $4.5-4.8 \times$ longer than its apical width, $1.10-1.15 \times$ longer than second segment. Penultimate segment (lateral view) $1.4-1.6 \times$ longer than wide, $0.5 \times$ as long as first segment, $0.8 \times$ as long as apical segment.

Mesosoma robust and high, its length 1.7-1.8× maximum height. Maximum width of mesoscutum $0.9-1.0 \times$ its median length. Median lobe of mesoscutum (dorsal view) almost straight anteriorly, but weakly concave medially. Notauli narrow anteriorly and wide posteriorly, densely rugulose-crenulate. Prescutellar depression wide anterolaterally, narrowed medially and laterally of scutellum sides, densely and coarsely striate, with very fine reticulation between striae, medially $0.3 \times$ as long as scutellum. Scutellum strongly convex, 1.7-1.8x longer than its maximum submedian width. Subalar depression entirely coarsely striate. Propodeum (lateral view) very weakly slanted in basal 0.6, then strongly and almost linearly slanted towards apex.

Wings. Fore wing 3.3-3.4x longer than its maximum width. Pterostigma 3.0$3.2 \times$ longer than wide. Radial (marginal) cell along metacarp (1-R1) $1.3 \times$ longer than pterostigma, maximum length of radial (marginal) cell 2.0-2.1× its maximum width. 


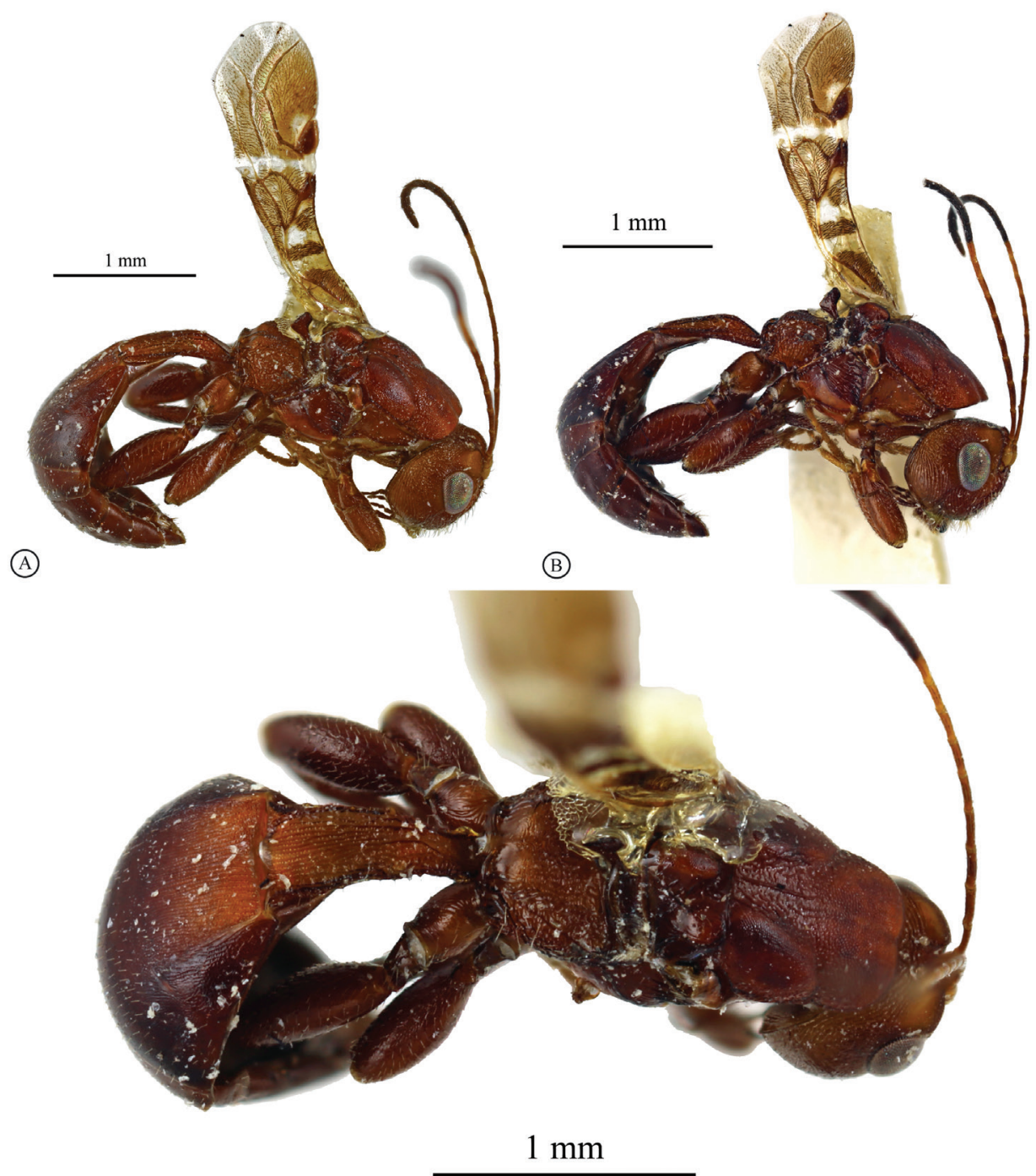

(C)

Figure 3. Spathioplites phreneticus, male holotype (MNHN) A habitus, lateral right view B habitus, lateral left view (photo flipped horizontally for comparison with right side depicted in $\mathbf{A}$ ) $\mathbf{C}$ habitus, dorsal view.

First radial abscissa ( $\mathrm{r}$ ) oblique to pterostigma, $0.8-0.9 \times$ as long as maximum width of pterostigma. First (r) and second (3-SR) radial abscissae forming very obtuse angle. Second radial abscissa (3-SR) 3.1-3.8x longer than first abscissa (r), 0.75-0.90x as long as weakly curved third abscissa (SR1), 2.6-2.8 $\times$ longer than first radiomedial vein (2-SR). Second radiomedial (submarginal) cell long and narrow, 3.6-4.3× longer than its maximum width, $1.45-1.50 \times$ longer than the brachial (subdiscal) cell. First medial abscissa $(1-\mathrm{SR}+\mathrm{M})$ distinctly curved. Recurrent vein $(\mathrm{m}-\mathrm{cu})$ as long as second abscissa 

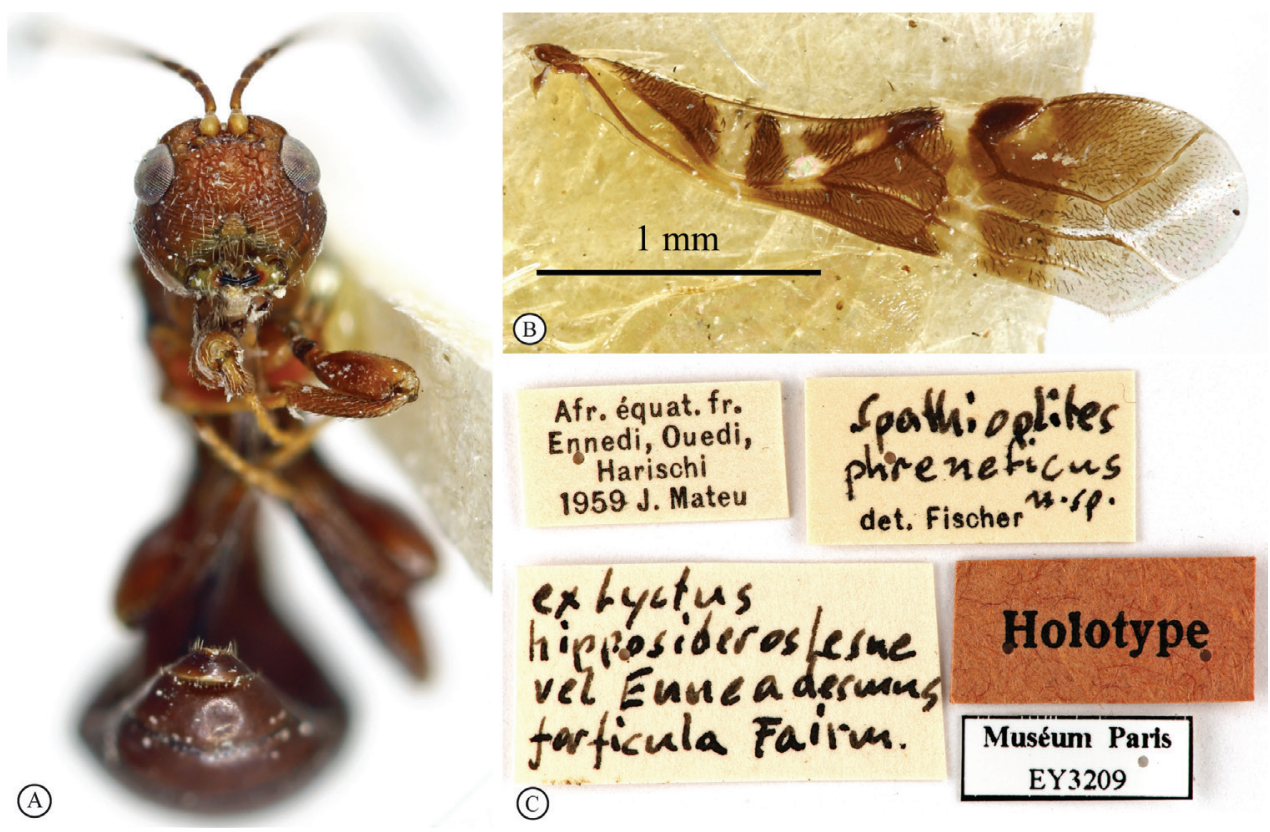

Figure 4. Spathioplites phreneticus, male holotype (MNHN) A head, anterior view B forewing, dorsal view $\mathbf{C}$ data labels.

of medial vein $(2-S R+M), 0.5 \times$ as long as first radiomedial vein $(2-S R)$. Discoidal (discal) cell narrow and rather short, 2.2-2.5× longer than wide. Basal (1-M) and recurrent $(\mathrm{m}-\mathrm{cu})$ veins strongly divergent. Distance $(1-\mathrm{CU} 1)$ from nervulus $(\mathrm{m}-\mathrm{cu})$ to basal vein (1-M) $0.3 \times$ nervulus ( $\mathrm{m}-\mathrm{cu}$ ) length, but rarely almost interstitial; nervulus (m-cu) straight and perpendicular to mediocubital vein (2-CU1). Hind wing 4.2-4.3 $\times$ longer than wide. Length of medial (basal) cell 6.5-7.0 $\times$ longer than maximum width.

Legs. Hind coxa 1.2-1.3× longer than its maximum width. Hind femur 2.52.6x longer than wide. Hind tarsus $1.1 \times$ longer than hind tibia. Hind basitarsus thickened, without ventral keel. Second tarsal segment $0.6-0.7 \times$ as long as basitarsus, $1.2 \times$ longer than fifth tarsal segment (without pretarsus).

Metasoma about as long as head and mesosoma combined. First tergite distinctly arched, dorsally and ventrally rather distinctly concave (lateral view), distinctly and almost linearly widened from base to apex (dorsal view). Maximum apical width of first tergite $2.5-2.8 \times$ its minimum width; length of tergite $1.4-1.5 \times$ its maximum width, about $1.7 \times$ length of propodeum. Median length of second tergite $0.9 \times$ its basal width, $1.4 \times$ length of third tergite. Length of second and third tergites combined 1.4-1.7x basal width of second tergite, $0.8-0.9 \times$ their maximum width. Ovipositor sheath $0.6-$ $0.7 \times$ as long as metasoma, $0.9 \times$ as long as mesosoma, $0.55-0.65 \times$ as long as fore wing.

Sculpture and pubescence. Vertex entirely densely and distinctly curvedly transversely striate with reticulation between striae, lateral tubercles densely reticulate-areolate, with fine aciculation in parts; frons entirely curvedly striate and with reticulation 


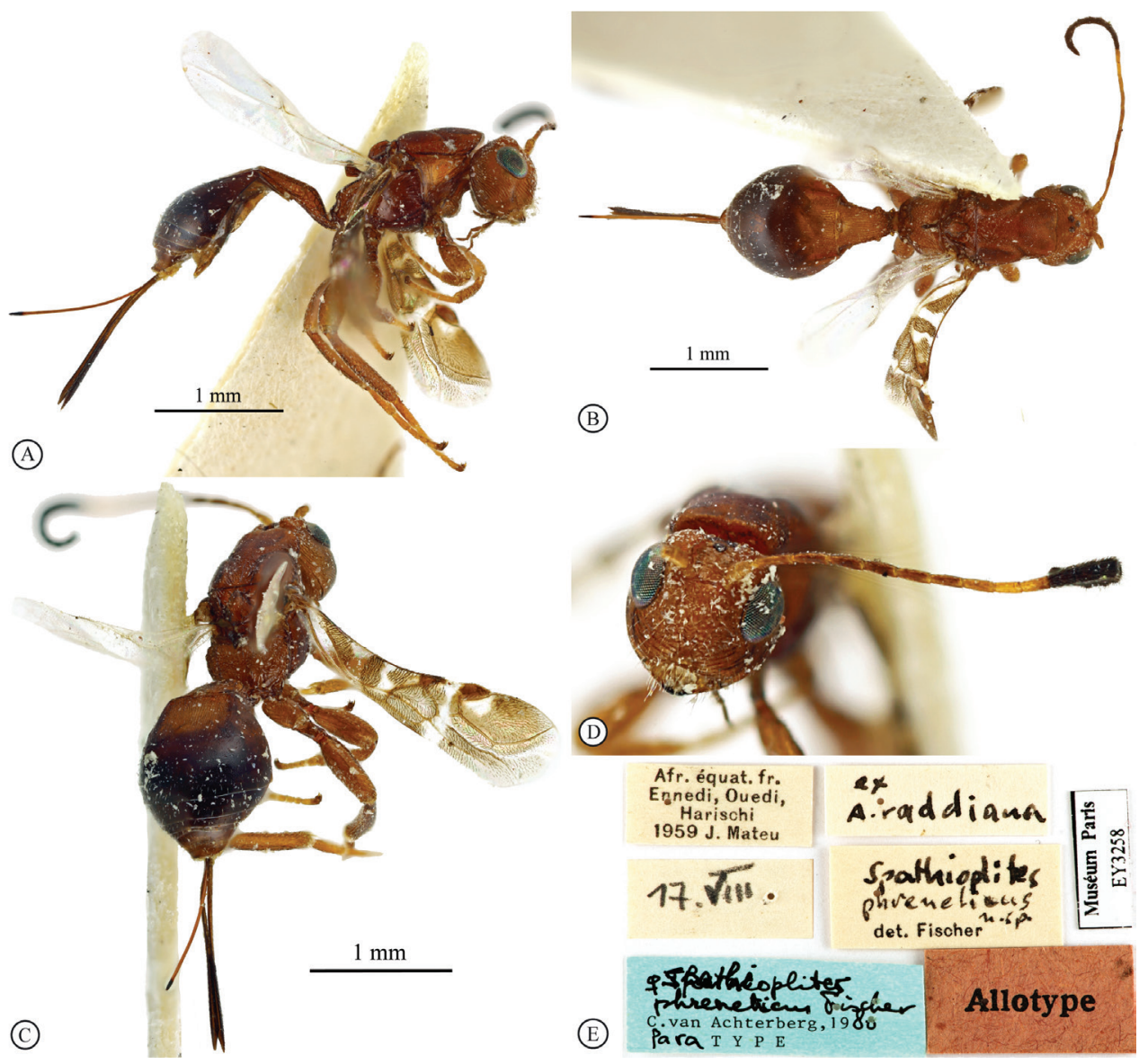

Figure 5. Spathioplites phreneticus, female paratype (MNHN) A habitus, lateral view B habitus, dorsal view $\mathbf{C}$ habitus, dorso-posterior view $\mathbf{D}$ head, antenna, anterior view $\mathbf{E}$ data labels

between striae; face coarsely and rather sparsely transversely curvedly striate with distinct rugosity between striae; temple subvertically curvedly striate, with subtransverse and fine striation along eye. Median lobe of mesoscutum densely and distinctly reticulate-areolate, lateral lobed finely and densely granulate, with coarse rugosity on rather narrow area in posterior 0.4 . Scutellum finely and very densely granulate. Mesopleuron smooth in lower half, transverse striate in upper half. Propodeum densely transversely striate with numerous dense rugosities in anterior 0.7 , sparsely or very sparsely longitudinally striate with smooth large areas. Hind coxa densely curvedly transversely striate dorsally or in dorsal half, finely reticulate-coriaceous to smooth in ventral half. Hind femur densely and finely reticulate-coriaceous becoming finer below or smooth in lower half. First tergite rugose-reticulate in basal 0.4 , distinctly and densely longitudinally striate with dense rugulosity between striae in apical 0.6. Second tergite densely and finely longitudinally striate with reticulation in basal 0.7 , densely and finely reticulate- 
areolate in apical 0.3 . Third tergite densely and finely reticulate-coriaceous becoming very fine posteriorly. Fourth and fifth tergites very finely coriaceous. Vertex with sparse, short and semi-erect pale setae almost entirely. Mesoscutum with very sparse and short semi-erect white setae, glabrous medially. Metapleuron mainly glabrous. Hind tibia dorsally with short, dense and adpressed pale setae; their length much less than maximum width of hind tibia.

Colour. Body light reddish brown, metasoma behind petiole reddish brown becoming dark reddish brown in posterior quarter; sometimes whole body darker. Antenna brownish yellow to light brown in basal 0.3, yellow medially, contrasted dark brown to black in apical quarter. Palpi reddish brown or dark reddish brown. Legs light reddish brown, hind coxa and tibia reddish brown or darker, hind tibia dark basally; rarely middle and hind legs mainly reddish brown. Fore wing strongly maculate, brown spots and stripes formed by brown or dark brown and dense setae, hyaline intermediate areas and stripes without any setae. Pterostigma brown, except for pale yellow to almost white basal quarter.

Male (holotype). Body length $5.2 \mathrm{~mm}$; fore wing length $2.7 \mathrm{~mm}$. Head behind eyes (dorsal view) strongly convex in anterior half. Transverse diameter of eye $0.75 \times$ as long as temple (dorsal view). POL 1.5 $\times$ Od. Eyes weakly directed forwards. Antenna 20-segmented. Scape $1.3 \times$ longer than its maximum width. First flagellar segment (front view) $4.5 \times$ longer than its apical width, as long as second segment. Penultimate segment (lateral view) $1.3 \times$ longer than wide. Mesosoma length $1.8 \times$ its maximum height. Prescutellar depression medially $0.2 \times$ as long as scutellum. Scutellum $2.0 \times$ longer than maximum submedian width. Fore wing $3.3 \times$ longer than its maximum width. Pterostigma $2.5 \times$ longer than wide. Radial (marginal) cell along metacarp (1-R1) $1.5 \times$ longer than pterostigma. First radial abscissa (r) $0.75 \times$ as long as maximum width of pterostigma. Second radial abscissa (3-SR) $3.4 \times$ longer than first abscissa (r), $0.85 \times$ as long as third abscissa (SR1), $2.2 \times$ longer than first radiomedial vein (2-SR). Second radiomedial (submarginal) cell $3.3 \times$ longer than its maximum width, $1.4 \times$ longer than the wide brachial (subdiscal) cell. Discoidal (discal) cell $2.1 \times$ longer than wide. Distance (1-CU1) from nervulus (cu-a) to basal vein ( $1-\mathrm{M}) 0.7 \times$ nervulus (cu-a) length. Hind wing $3.9 \times$ longer than wide. Length of medial (basal) cell about $6.0 \times$ longer than maximum width. Hind coxa $1.3 \times$ longer than maximum width. Hind femur $2.4 \times$ longer than wide. Metasoma $1.5 \times$ longer than head and mesosoma combined. Maximum apical width of first tergite $2.3 \times$ its minimum width; length of tergite $1.8 \times$ its maximum width, $1.6 \times$ length of propodeum. Length of second and third tergites combined $1.8 \times$ basal width of second tergite, $0.8 \times$ their maximum width. Body overall darker than in female. Scape and pedicel of antenna yellow. Legs reddish brown, all coxae paler. Pterostigma dark brown, almost white in basal third. Otherwise similar to female.

Biology. According to the original label present on the holotype specimen the host of this species could either be wood-boring Lyctus hipposideros Lesne, 1908, or Enneadesmus forficula (Fairmaire, 1883) (Coleoptera, Bostrichidae). A label on the paratype reads "ex A. raddiana" = Acacia raddiana Savi, which is currently considered to be a subspecies of the Umbrella thorn acacia: Vachellia tortilis subsp. raddiana (Savi) Kyal. 
\& Boatwr. The northern African specimens were collected in mid to late northern hemisphere summer (May and August), and the two South African specimens were collected in the latter half of the southern hemisphere summer (between 10 February and 9 May). Seasonal variation in arid habitats can be pronounced as shown in figures 6 and 7 depicting the sampling locality in Tswalu Game Reserve (South Africa). Dead wood was gathered from the surrounding vicinity and stacked under the Malaise trap to increase return on parasitoids of wood-boring hosts (Fig $7 \mathrm{C}$ ), and it is likely that the $S$. phreneticus specimens emanated from this source that probably contained woodboring host beetle larvae.

Comments. The long-term continuous inventory survey sites deployed in Tswalu Kalahari Game Reserve generated 186 bulk samples of insects, comprising thousands of specimens, of which 25 of 42 Malaise trap samples have had the Hymenoptera extracted and sorted to family. Only two female specimens of Spathioplites phreneticus were recovered from the 25 samples processed, and these were both from one (TSW15DED3) of the five sites sampled with Malaise traps. The habitat of this sampling site is depicted in Figs 6 C-D and Figs 7 A-F. The two females were collected between 10 February and 9 May 2016 during a below average rainfall summer season. The sampling localities across the five different vegetation types are depicted in Fig 6 E. The only site that returned S. phreneticus specimens was situated in Olifantshoek Plains Thornveld.

Distribution. (Fig. 6). Chad, Senegal and South Africa.

\section{Discussion}

Spathioplites phreneticus is probably an arid-adapted species, based on the current distribution and habitats of the sampled localities. The extreme disparity in the northern Chad and southern South African localities ( $4900 \mathrm{~km}$ apart) is likely determined by the disjunct north-south aridity patterns of the African continent (Masih et al. 2014). Given the additional far western record in Senegal ( $4000 \mathrm{~km}$ west of the type locality), the distribution of the species in northern Africa is likely to be associated with the arid Sahel transverse belt south of the Sahara (Fig. 6 B). The disrupted north-south distribution pattern emulates that of the pycnostigmine figitids (Cynipoidea) (Buffington and van Noort 2007), which also exhibit a similar fragmented distribution pattern, as do a number of other taxa, such as butterflies (Carcasson 1964), masarine wasps (Gess 1992), flies (Bowden 1978), mammals (Grubb 1999; Grubb et al. 1999; Vrba 1992) and plants (White 1983). As for Spathioplites, no pycnostigmine specimens have ever been collected in the mesic intervening areas of central Africa (Buffington and van Noort 2007). Masarine wasps (Vespidae) also exhibit this biogeographical pattern (Gess 1992), suggesting a similar historical evolutionary driving process for these groups of wasps. Historical physiographical change would have driven climate change and hence adaptation of vegetation type and habitat. Aridification of southern Africa commenced around 20 million years ago with the formation of the cold Benguela current upwelling system, which removed the moisture supply to the interior of the 


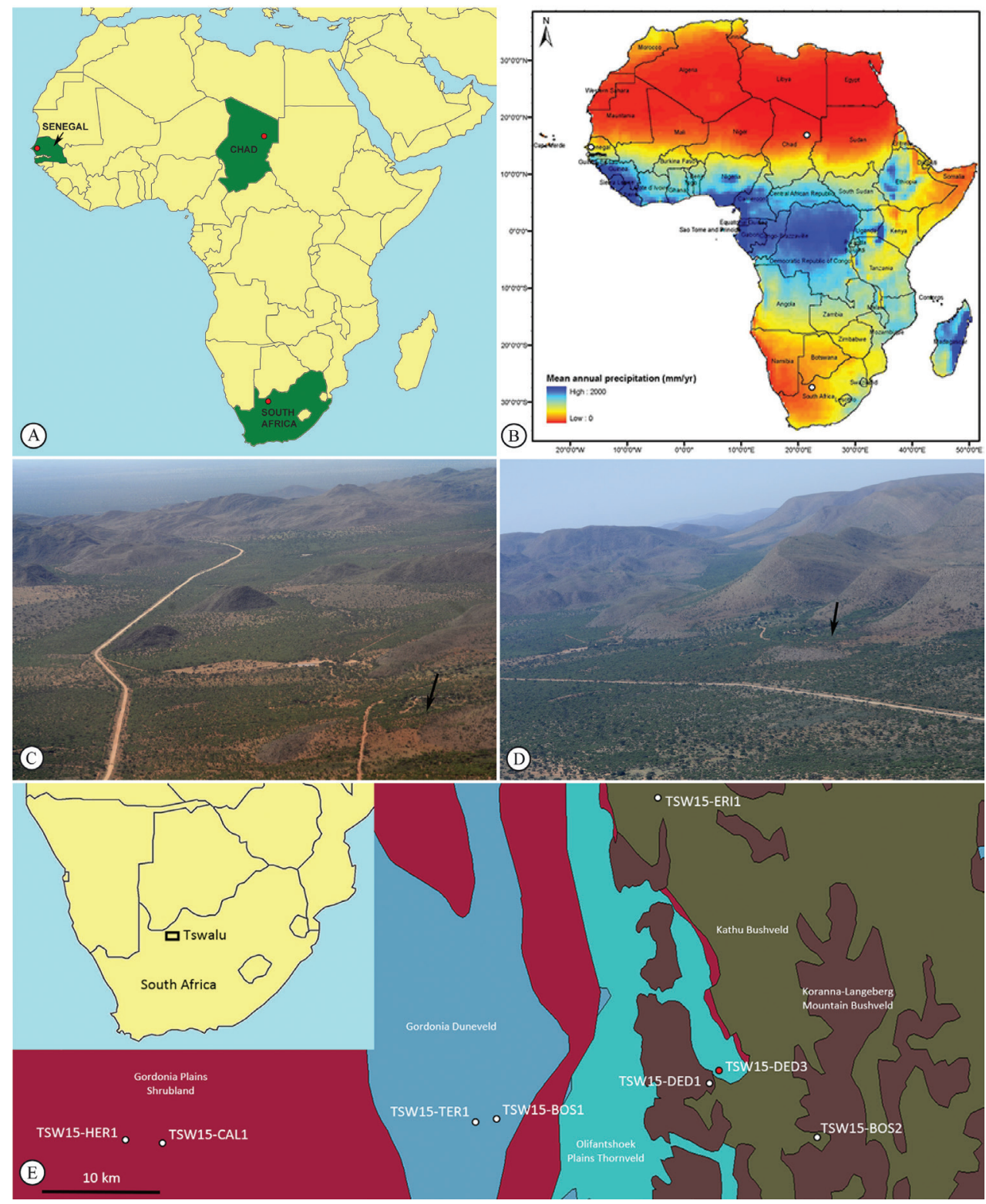

Figure 6. Spathioplites phreneticus $\mathbf{A}$ political distribution map. Only known from three localities (depicted by red circles) one each in Chad, Senegal and South Africa B distribution localities (depicted by white circles) mapped onto African precipitation patterns. Data source: ERA-Interim corrected with GPCP v2.1; period: 1979-2010. After Masih et al. 2014 and Trambauer et al. 2014 C habitat South African sampling site locality TSW15-DED3 in Tswalu Kalahari Game Reserve, aerial view from North in February 2016 after summer rains (locality arrowed) D habitat South African locality TSW15-DED3 in Tswalu Kalahari Game Reserve, aerial view from East in February 2016 after summer rains (locality arrowed) E sampling localities in Tswalu Game Reserve plotted onto vegetation map after Mucina and Rutherford (2006); red circle depicts S.phreneticus locality TSW15-DED3, white circles depict other sampling localities. 


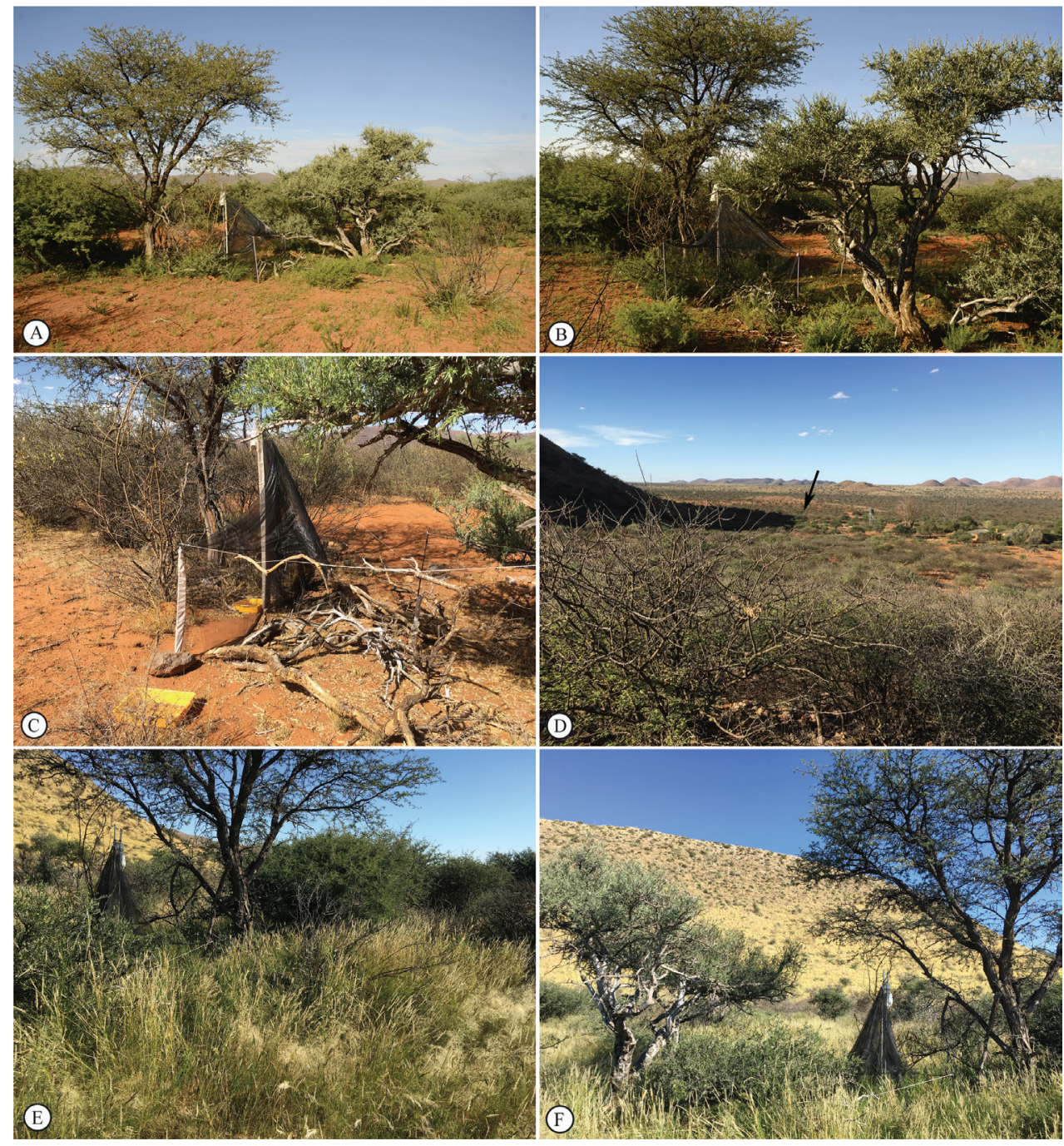

Figure 7. Spathioplites phreneticus South African sampling site locality TSW15-DED3 in Tswalu Kalahari Game Reserve showing seasonal changes in habitat A habitat May 2016, after poor summer rains B habitat May 2016, after poor summer rains C habitat Nov 2016 at end of dry winter season showing dead wood stacked under Malaise trap to increase return on parasitoids of wood-boring hosts (Malaise trap damaged by game animals prior to fixing) D habitat overview Nov 2016 (locality arrowed) at end of dry winter season E habitat May 2017, after good summer rains $\mathbf{F}$ habitat May 2017, after good summer rains.

continent from the Atlantic Ocean. The process of drying out was further enhanced by upliftment of the continent (the African Super Swell), a process resulting in an increase in the height of the eastern escarpment, further establishing the east-west rainfall gradient (King 1978; McCarthy and Rubidge 2005).

The contemporary northern and southern arid areas of the African continent were linked in the past. A period of cooling in the middle Miocene 15.6-12.5 million years ago (Denton 1999), and during repeated interglacial periods of the Pleistocene 
epoch when forests in tropical Africa contracted considerably, forming refugia with a corresponding expansion of more xeric environments (Axelrod and Raven 1978; Denton 1999) resulted in an eastern swath of aridity on the African continent. Buffington and van Noort (2007) hypothesized that the historical distribution of pycnostigmine wasps would have been affected by these phases of being alternately continuous and disjunct, culminating in the current phase of distributional vicariance. This is a plausible hypothesis of underlying evolutionary drivers that may also have determined the contemporary distribution for Spathioplites phreneticus.

Spathioplites phreneticus is probably not rare and is simply under-sampled due to lack of collecting in arid environments that are often perceived to be depauperate in terms of insect species-richness. Emergence of adult $S$. phreneticus is likely to occur during a very short window of suitable environmental conditions. Arid areas are usually highly seasonal with sporadic rainfall events. When these precipitation events do occur an explosion of adult invertebrate activity ensues, which may be short-lived. These cycles of population explosion may only occur every couple of years and often are not an annual event, further hindering collection of adult wasps. The invertebrate inventory surveys run by Simon van Noort over the last 30 years have been designed to be continuous and long-term (preferably a minimum of a year), but ideally they are run for at least 5 years to cover annual variations in wasp emergence. This strategy means that periods of short-burst activity do not need to be predicted as traps are already in place to obtain return when these events occur. Continuous sampling also means that during periods of perceived non-optimal environmental conditions (which historically have not been sampled, because of a perception of lack of activity) rare taxa that only emerge during these periods are sampled, such as species of Nixonia Masner, 1958 that emerge as adults during the hot and dry unproductive ecological period in the summer months (van Noort and Johnson 2009). The two Spathioplites females that were collected between February and May 2016 encompassed the mid to end period of the wetter summer season. The collecting of these specimens is likely a result of the dead wood that was gathered from the surrounding vicinity and stacked under the Malaise trap to increase chances of collecting parasitoids of wood-boring hosts (Fig. 7 C). This approach was also used at the other surveyed localities, which were situated in different vegetation types: Gordonia Plains Shrubland, Gordonia Duneveld, Kathu Bushveld and Koranna-Langeberg Mountain Bushveld in the Kalahari ecosystem, vegetation classification after Mucina and Rutherford (2006). The site that returned the S. phreneticus specimens was situated in Olifantshoek Plains Thornveld, and these preliminary results suggest that there may be habitat fidelity, as no specimens were recovered from any of the samples emanating from the other vegetation types.

Implementation of long-term invertebrate inventory surveys are critical to assess seasonal variability and natural longer-term climatic cycles affecting composition of invertebrate faunal assemblages over time. These surveys, however, produce huge numbers of specimens, requiring availability of substantial resources for sorting the bulk samples, and subsequent curation and identification of specimens. Further specimens of $S$. phreneticus may very well still emerge from the remaining unprocessed samples collected during the invertebrate survey of Tswalu Kalahari Private Game Reserve. 


\section{Acknowledgements}

Thanks to Tswalu Foundation, Duncan McFayden and Dylan Smith for facilitating SvN's research on Hymenoptera in Tswalu Kalahari Private Game Reserve. To Tswalu Foundation Trust for partly funding the invertebrate inventory survey, and to Tswalu conservation students, Prince Ngomane, Kelsey Green (2015), Clement Motau, Lise Bredenkamp and Tara Naeser (2016), for guidance and assistance in the field. Thank you to Manuela Vizek for providing specimen data of the paratypes deposited in NHMW. SvN was funded by South African National Research Foundation grants: GUN 2068865; GUN 98115. SB was in part funded by grants provided by the Russian Foundation for Basic Research (project No. 19-04-00027) and the Russian State Research Project No. AAAA-A19-119020690101-6. Thank you to the Northern Cape Department of Nature and Environmental Conservation for providing collecting and export permits. Thank you to Denis Brothers, Cornelius van Achterberg and Michael Sharkey for critically reviewing the manuscript.

\section{References}

Axelrod DI, Raven PH (1978) Late Cretaceous and Tertiary vegetation history of Africa. In: Werger MAJ (Ed.) Biogeography and Ecology of Southern Africa, W. Junk, The Hague, 77-130. https://doi.org/10.1007/978-94-009-9951-0_5

Belokobylskij SA (1992) On the classification and phylogeny of the braconid wasps subfamilies Doryctinae and Exothecinae (Hymenoptera, Braconidae) Part 1. Entomologicheskoe Obozrenie 71(4): 900-927. [Entomological Review 72(6): 109-137.]

Belokobylskij SA (1995) Two new genera and two new subgenera of the subfamilies Exothecinae and Dorcytinae from the Old World (Hymenoptera: Braconidae). Zoölogische Mededeelingen 69: 37-52.

Belokobylskij SA (2002) Two new Oriental genera of Doryctinae (Hymenoptera, Braconidae) from termite nests. Journal of Natural History 36(8): 953-962. https://doi. org/10.1080/00222930110048927

Belokobylskij SA (2015) Review of species of the Old World genus Doryctophasmus Enderlein, 1912 (Hymenoptera: Braconidae: Doryctinae). Zootaxa 3985(4): 541-564. https://doi. org/10.11646/zootaxa.3985.4.4

Belokobylskij SA, Maeto K (2009) Doryctinae (Hymenoptera: Braconidae) of Japan. Fauna Mundi Volume 1. Natura optima dux Foundation, Warsaw, 806 pp. https://doi. org/10.3161/067.058.0107

Belokobylskij SA, Quicke DLJ (2000) Seven new genera of the subfamily Doryctinae (Hymenoptera: Braconidae) from Old World. Journal of Hymenoptera Research 9(1): 111-141.

Belokobylskij SA, Zaldívar-Riverón A, Quicke DLJ (2004) Phylogeny of the genera of the parasitic wasps subfamily Doryctinae (Hymenoptera: Braconidae) based on morphological evidence. Zoological Journal of the Linnean Society 142(3): 369-404. https://doi. org/10.1111/j.1096-3642.2004.00133.x 
Bowden J (1978) Diptera. In: Werger MAJ (Ed.) Biogeography and Ecology of Southern Africa, W. Junk, The Hague, 775-796. https://doi.org/10.1007/978-94-009-9951-0_25

Buffington ML, van Noort S (2007) A world revision of the Pycnostigminae (Cynipoidea: Figitidae) with descriptions of seven new species. Zootaxa 1392(1): 1-30. https://doi. org/10.11646/zootaxa.1392.1.1

Carcasson RH (1964) A preliminary survey of the zoogeography of African butterflies. East African Wildlife Journal 2(1): 122-157. https://doi.org/10.1111/j.1365-2028.1964.tb00203.x

Denton GH (1999) Cenozoic climate change. In: Bromage TG, Schrenk F (Eds) African Biogeography, Climate Change and Human Evolution, Oxford University Press, Oxford, 94-114.

Fischer M (1962) Neue Braconiden-Parasiten von schädlichen Insekten (Hymenoptera). Zeitschrift für Angewandte Entomologie 49(1-4): 297-312. https://doi. org/10.1111/j.1439-0418.1961.tb02868.x

Gess SK (1992) Biogeography of the masarine wasps (Hymenoptera: Vespidae: Masarinae), with particular emphasis on the southern African taxa and on correlations between masarine and forage plant distributions. Journal of Biogeography 19(5): 491-503. https:// doi.org/10.2307/2845768

Grubb P (1999) Evolutionary processes implicit in distribution patterns of modern African mammals. In: Bromage TG, Schrenk F (Eds) African Biogeography, Climate Change and Human Evolution, Oxford University Press, Oxford, 150-164.

Grubb P, Sandrock O, Kullmer O, Kaiser TM, Schrenk F (1999) Relationships between eastern and southern African mammal faunas. In: Bromage TG, Schrenk F (Eds) African Biogeography, Climate Change and Human Evolution, Oxford University Press, Oxford, 253-267.

Jasso-Martínez JM, Belokobylskij SA, Zaldívar-Riverón A (2019) Molecular phylogenetics and evolution of generic diagnostic morphological features in the doryctine wasp tribe Rhaconotini (Hymenoptera: Braconidae). Zoologischer Anzeiger 279: 164-171. https:// doi.org/10.1016/j.jcz.2019.02.002

King L (1978) The geomorphology of Central and Southern Africa. In: Werger MAJ (Ed.) Biogeography and Ecology of Southern Africa, W. Junk, The Hague, 1-17. https://doi. org/10.1007/978-94-009-9951-0_1

Masih I, Maskey S, Mussá F, Trambauer P (2014) A review of droughts on the African continent: A geospatial and long-term perspective. Hydrology and Earth System Sciences 18(9): 3635-3649. https://doi.org/10.5194/hess-18-3635-2014

Masner L (1958) An interesting new genus of Scelionidae from S.W. Africa (Hymenoptera: Proctotrupoidea). Proceedings of the Royal Entomological Society of London (B) 27(7-8): 101-104. https://doi.org/10.1111/j.1365-3113.1958.tb00420.x

McCarthy T, Rubidge B (2005) The story of Earth \& Life. A southern African perspective on a 4.6-billion-year journey. Struik Publishers, Cape Town, 336 pp.

Mucina L, Rutherford MC [Eds] (2006) The vegetation of South Africa, Lesotho and Swaziland. SANBI, Pretoria, 807 pp.

Nees von Esenbeck CG (1819) Appendix ad J.L.C. Gravenhorst conspectum generum et familiarum Ichneumonidum, genera et familias Ichneumonidum adscitorum exhibens. Nova Acta Physico-Medica Academiae Caesareae Leopoldino-Carolinae 9: 299-310. 
Nixon GEJ (1943) A revision of the Spathiinae of the Old World (Hymenoptera, Braconidae). Transactions of the Royal Entomological Society of London 93(2): 173-456. https://doi. org/10.1111/j.1365-2311.1943.tb00434.x

Trambauer P, Maskey S, Werner M, Pappenberger F, van Beek LPH, Uhlenbrook S (2014) Identification and simulation of space-time variability of past hydrological drought events in the Limpopo River basin, southern Africa. Hydrology and Earth System Sciences 18(8): 2925-2942. https://doi.org/10.5194/hess-18-2925-2014

van Achterberg C (1993) Illustrated key to the subfamilies of the Braconidae (Hymenoptera: Ichneumonoidea). Zoölogische Verhandelingen 283: 1-189.

van Noort S (2021) WaspWeb: Hymenoptera of the Afrotropical region. http://www.waspweb. org [Accessed: 6.September.2021]

van Noort S, Johnson NF (2009) New species of the plesiomorphic genus Nixonia Masner (Hymenoptera, Platygastroidea, Platygastridae, Scelioninae) from South Africa. Advances in the systematics of Hymenoptera. Festschrift in honour of Lubomír Masner. ZooKeys 20: 31-51. https://doi.org/10.3897/zookeys.20.112

Viereck HL (1911) Descriptions of six new genera and thirty-one new species of Ichneumon flies. Proceedings of the United States National Museum 40(1812): 173-196. https://doi. org/10.5479/si.00963801.1812.173

Vrba ES (1992) Mammals as a key to evolutionary theory. Journal of Mammalogy 73(1): 1-28. https://doi.org/10.2307/1381862

White F (1983) The vegetation of Africa. A descriptive memoir to accompany the Unesco/ AETFAT/UNSO vegetation map of Africa, Unesco, Paris, 356 pp.

Yu DS, van Achterberg C, Horstman K (2016) Taxapad 2016, Ichneumonoidea 2015. Nepean, Ontario. Database on flash-drive.

Zaldívar-Riverón A, Belokobylskij SA, León-Regagnon V, Briceño R, Quicke DLJ (2008) Molecular phylogeny and historical biogeography of the cosmopolitan parasitic wasp subfamily Doryctinae (Hymenoptera: Braconidae). Invertebrate Systematics 22(3): 345-363. https://doi.org/10.1071/IS07028 